\title{
VERTICAL PLANT PRODUCTION AS A PUBLIC EXHIBIT AT PAIGNTON ZOO
}

\author{
Kevin L. Frediani ${ }^{1}$
}

\begin{abstract}
Paignton Zoo has undertaken a novel project together with a multinational plant technology group to build Europe's first vertical growing facility. The project represents the first zoo-based sustainable growing laboratory. It is an example of how zoos and botanic gardens can demonstrate sustainability to their visitors, through reducing their own impacts on the environment and by using plant-based solutions to offset the impact of anthropogenic global change on biodiversity. Urban agriculture and High Density Vertical Growing technology should be seen as a valuable element that can help to achieve the Millennium Development Goals, most specifically goal number one: to end poverty and hunger, and goal number seven: to ensure environmental sustainability by taking pressure off habitats to service unsustainable cities through agricultural domestication or otherwise unsustainable land use.
\end{abstract}

\section{INTRODUCTION}

Paignton Zoo Environmental Park is a zoo and botanic garden in the south-west of England. It was opened to the public in 1923 as a private collection of animals and plants by Herbert Whitley, the heir to a brewery fortune (Baker, 1988). Whitley died in 1955, and the garden was entrusted in 1958 as an educational, research and conservation charity. Since that time it has operated as an education and research charity dedicated to wildlife conservation. It achieves this work through in situ and ex situ work abroad and through managed population work on its own site that is carried out in collaboration with other scientifically managed reserves and collections. This is underpinned through fieldwork in a number of countries around the world (Whitley Wildlife Conservation Trust, 2009). In 2005, to demonstrate congruence in its site operations and in undertaking new developments, the zoo gained external recognition for its work by implementing the internationally recognised standard of environmental management, ISO 14001. This is a reiterative standard that requires rigorous annual auditing under external auditors to retain (Turner, 2009).

\section{PLANT USE IN THE ZOO}

Over the years Paignton Zoo has built up a large botanic collection which today hosts over 5,000 plant accessions growing in its public areas outside the animal exhibits. These

1. Kevin Frediani is Curator of Plants and Gardens at Paignton Zoo Environmental Park.

Address: Totnes Road, Paignton, Devon.

Email: Kevin.frediani@paigntonzoo.org.uk 
represent 2,500 species that are set in 30ha of natural rolling Devon landscape. While the zoo is internationally recognised for the integrated nature of its work, the gardens have not had the same directed focus with its plant collections until recently; instead an emphasis had been placed upon accumulating and showing plant diversity. Since 2008 the garden collections have been provided with a new vision that looks to optimise the potential for plants to support the zoo's mission: protecting our global wildlife heritage and inspiring in people a respect for animals, plants and the environment. Through this new initiative the garden is progressing in a new botanical direction by following an integrated approach to zoo horticulture (Frediani, 2009a; Frediani, 2010).

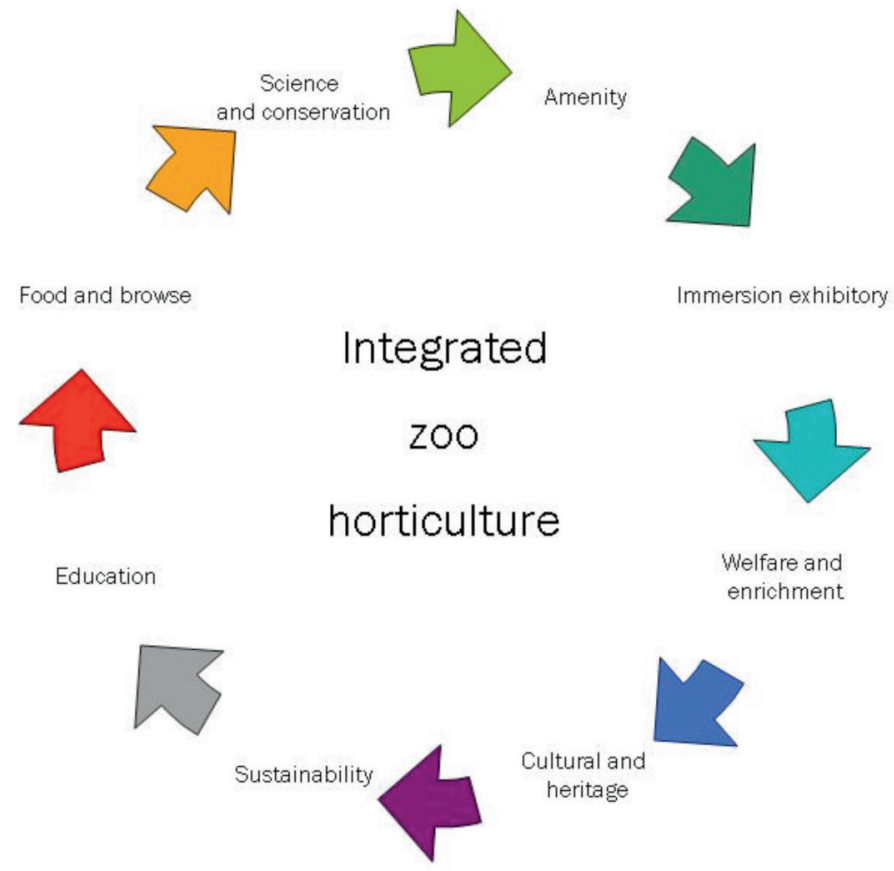

Fig. 1 Eight themes for the use of plants that define the breadth of zoo horticulture (after Frediani, 2009a).

Many of the plant-use themes are widely understood and easily achieved as they relate to well-established roles of botanic gardens around the world, such as display, education and research. A small number, however, required further exploration and creative thinking to help realise. Food production requires land to be made available and potentially conflicts with animal exhibits where welfare priorities make land a highly sought-after commodity. The theme of Enrichment first had to be defined in terms of the use of landscape and plants before it could be utilised practically to encourage natural behaviour in animals (Frediani, 2009b), while Sustainability as a theme proved rather difficult to interpret in terms of tangible developments for visitors to see, interpret and enjoy. 


\section{VERTICROPTM - HIGH DENSITY VERTICAL GROWING}

VertiCrop ${ }^{\mathrm{TM}}$ uses hydroponic growing technology in a vertical system. Hydroponics is the science of growing plants without soil. Instead of soil, plants are grown in a solution containing all the necessary mineral elements. Methods used to get the oxygen and nutrients to the roots include bare root systems and systems using inert substrates to support the plants. The Paignton Zoo system comprises a closed-loop conveyor system suspended from an overhead rack that carries seventy hangers holding eight pairs of bespoke growing trays using a water-based bare root system contained in a plastic tray (Fig. 2). This allows an even airflow over plants and, importantly, equal exposure to light. It is integrated with the most advanced hydroponics technologies to automatically supply water and nutrients at a central feeding station. Any run-off solutions are captured, filtered and recycled through the whole irrigation system. In a little over $100 \mathrm{~m}^{2}$ of floor space there is the capacity to grow 11,200 plants at any one time (Frediani, 2010). The system at Paignton Zoo currently produces around 112 lettuces per square metre, on a pilot system $3 \mathrm{~m}$ high. However, optimal production of up to 250 lettuces per $\mathrm{m}^{2}$ can be obtained if the vertical dimension is $6 \mathrm{~m}$ high. VertiCrop ${ }^{\mathrm{TM}}$ forecasts based upon this modelling suggest annual yields of lettuce of around 50 times higher per square metre than typical field-grown crops (Bayley et al., 2010).

\section{SUSTAINABLE FOOD PRODUCTION AS A PUBLIC EXHIBIT}

In order to address the nutritional requirements of zoo animals an intimate knowledge of the animals and their foodstuff is required. Nutritionists can be supported in this work if they are given the opportunity to measure the content of the food and then exercise more control over the nutrient content of the food crops (Morgan, 2009). This can be achieved with modern horticultural crop production technology but to date has not been widely explored. For instance, consider the difference in nutrient content between different members of the Brassicaceae family or how the roots of plants which are traditionally left behind in the ground or removed and composted at cropping time could also yield nutrients or protein if only they were quantified and harvested. These roots can be fed to the animals as part of an enrichment or welfare programme reducing waste and increasing fibre intake, while nutritional difference between varieties and species can be exploited to optimise an animal's dietary intake.

These benefits can be achieved through localised crop production or contract growing of specialist crops specified by the zoo, although this often incurs large cost and takes time to manage successfully. Locally produced crops can reduce costs, provide greater control and improve flexibility. These benefits are even greater where organisations can grow their own food plants to serve their own needs. In zoos, as in urban communities, food provision is heavily subsidised and therefore undervalued. There is wide misuse of carbon-based fuels to grow, transport and maintain crops for market right through to a post-harvest regime that stores food until it is required for use. With the VertiCrop ${ }^{\mathrm{TM}}$ system of production in the zoo it is now possible to grow food on a 
site that is limited in space and that services some of the animals' needs for fresh leafy salad crops year round in a sustainable, low-impact but highly interpretational manner. A number of benefits have been gained from growing foods that were not quantifiable at the outset of the project (Frediani, 2009c). These have included a wider diversity of crop plants than were commercially thought possible or were previously available through wholesaler purchase locally, the provision of plants year round without concern for changes in weather and impacts on field-grown crops, the ability to provide crops that are out of season or out of the price range of the organisation and the reduction of the overall food bill which in turn has led to an increase in the food security of the organisation.

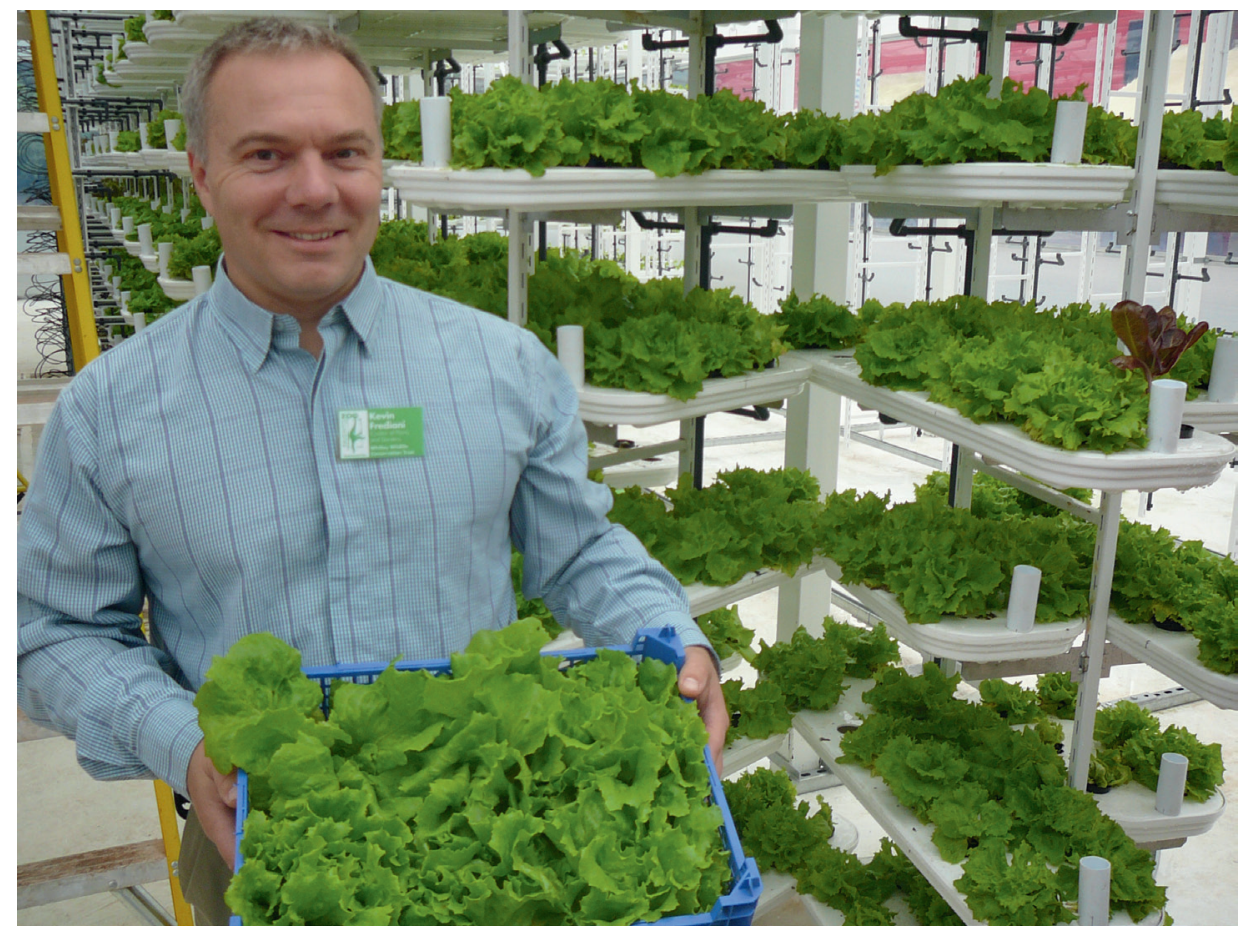

Fig. 2 Kevin Frediani displays the VertiCrop ${ }^{\mathrm{TM}}$ growing production system and the first crop of lettuces. Photo: Phil Knowling.

THE GLOBAL CONTEXT OF THE MODERN ZOO AND BOTANIC GARDEN

Over the last five decades the pursuit of economic growth has been the single most important policy goal for most countries across the world. The global economy has grown to almost five times the size it was only half a century ago, but this growth is now increasingly being seen as unsustainable. Future projections estimate that continued growth at this rate will result in an economy 80 times the current size by the year 2100, leading one influential world economist to redefine our age as following 
a "myth of economic growth" (Jackson, 2009). Jackson, as chair of the UK government's Sustainable Development Commission, highlights the extraordinary ramping up of global economic activity while pointing out that it has no historical precedent, and that it is at odds with our scientific knowledge of the finite resource base and the fragile ecology on which we depend for survival. Further, he notes that the past pursuit of growth has already been accompanied by the degradation of an estimated 60 per cent of the world's ecosystems (Jackson, 2009). This is an unsustainable misuse of the world's life support systems, which are essential for the well-being of mankind (Odum, 1993).

Given the state of human impacts on the world, it could be argued that there is a moral duty for zoos and botanic gardens to showcase the sustainable use of resources such as energy, land and water on their own sites to directly make the link between the global and local impact of sourcing, growing, housing and displaying collections of rare plants and animals. How otherwise can conservation organisations build exhibits to educate visitors about the loss of biodiversity due to habitat destruction or climate change without having demonstrated a commitment to working within the limits of sustainable growth and development themselves? (Frediani, 2009a). To undertake this congruently, gardens must audit their own impacts through understanding how they operate as a business, including how they obtain and use their resources. This information can then be used to measure the environmental footprint of the organisation or, more tactically, of a new exhibit. It can be used to inform development as project proposals are first modelled and then modified to obtain their best performance before being built.

The environmental footprint is a useful way to measure the ability of an organisation to work within sustainable limits where carbon is an indirect measure of the environmental cost of operations and activities (Weidema et al., 2008). When this calculation is applied to growing food crops on-site using VertiCrop ${ }^{\mathrm{TM}}$, little or no carbon is expended between crop production and delivery. Transportation is eliminated and the environmental costs are therefore reduced. The exhibit at Paignton Zoo is housed within a low-energy polythene structure that is double skinned with the 'smart film' THB Luminance polythene sourced from XL Horticulture. This type of double skin retains heat, reduces scorch and provides optimal light levels in the winter months (Chester, 2010). Rainwater is harvested from the roof, and underfloor heating is used to provide minimum winter temperatures. Further reductions can be made through integration of the system with compatible green technologies to generate the energy required to operate it. These include biogas, solar thermal, air, ground and gas source heat pumps, photovoltaics, geothermal and wind power. If the exhibit were to use these technologies in future no carbon-based energy may be required to run it and it would provide the organisation with a reduced ecological footprint that could be communicated to its visitors in a visually graphic and physical way, by literally eating the view! 


\section{Sustainable Greenhouse}

The vertical growing system maximises plant production using a soil-less hydroponic method.

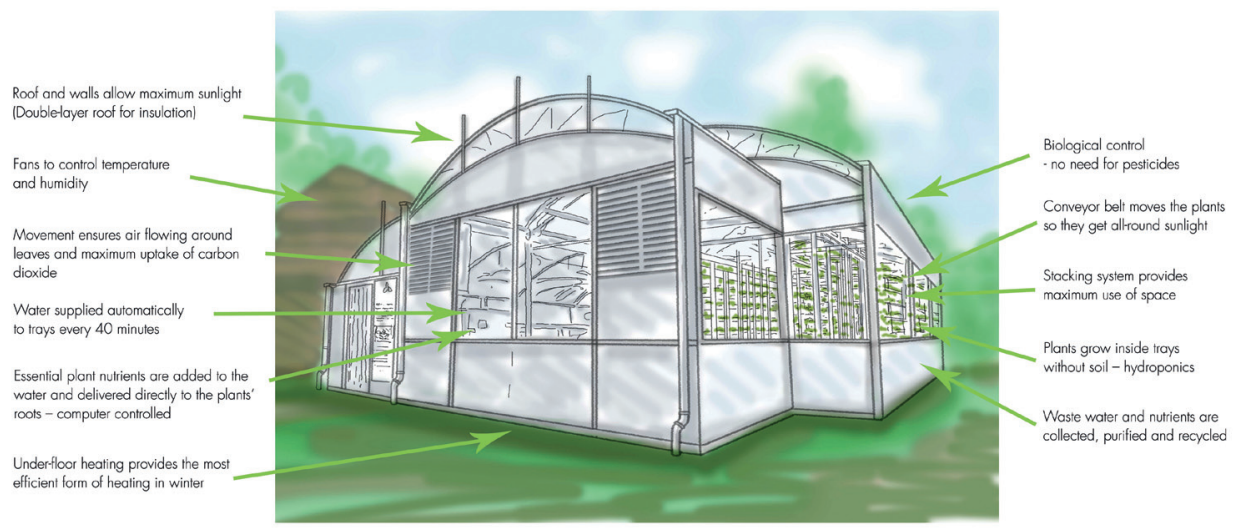

Fig. 3 VertiCrop ${ }^{\mathrm{TM}}$ exhibit interpretation at Paignton Zoo showcasing sustainable food production. Photo of interpretation board: Chris Mutter.

\section{URBAN FOOD PRODUCTION}

Energy inputs are critical to agricultural production, and the increased use of fossil fuel energy is an issue, particularly in developed countries and increasingly in developing countries. Even though agriculture requires only a very small percentage of all the fossil fuel resources used worldwide, long-term sustainability of global agricultural production will require renewable alternative energy resources (Mears, 2007). In an increasingly urban world where the majority of people now live in cities, localisation requires that food and fuel be produced in an urban context (Crane \& Kinzig, 2005). At present, there are no examples of a locally sustained urban community anywhere in the world (Odum \& Garret, 2005; Newman \& Jennings, 2008). Urban agriculture is now being recognised as one of the activities with the potential to contribute towards socio-economic development in urban areas of the developing world. However, urban sustainability is yet to be realised, primarily because urban agriculture presents a number of technological challenges (Fischetti, 2009; Vogal, 2008). The main challenge is lack of growing space and limited water supplies. So far there is only one successful example, in Havana, Cuba, with the large-scale conversion of green space following the collapse of external political support from former communist countries in the late twentieth century.

The Cuban experience shows that with massive political support and through the use of more sustainable land management practices based upon core permaculture principles, it is possible to make a huge improvement in local food production. Although the daily food intake per person in this instance remained below the recommended daily amount it did support the urban population without massive external input and imports of food (Cruz \& Medina, 2003). 
In developing countries urban agriculture is increasingly being seen as a progressive way forward. In Zambia, urban agriculture has played a key role as one of the major community responses to the aftereffects of economic restructuring and therefore has the capacity to contribute towards alleviating food insecurity and poverty (Hampwaye et al., 2009).

\section{VERTICAL GROWING BEYOND THE ZOO}

Vertical growing systems are proposed as possible solutions for increasing urban food supplies without increasing the need for additional areas of land to be put aside for agriculture (Despommier, 2010). They can have a role alongside permaculture systems in cities and low-impact agriculture in soils around cities. The primary advantage of vertical growing is the high-density production it allows using a much reduced physical footprint and fewer resources relative to conventional agriculture. The figures suggest a water use efficiency of one-sixteenth of that required by conventional agriculture and provision of 20 times the crop per unit of land (Bayley et al., 2010).

Vertical growing is compatible with existing hydroponics and greenhouse technologies and can embrace emerging sustainable technologies such as LED and plasma lighting. Together these solutions address many aspects of the sustainable urban production challenge, such as the need to be soil-free, the preference for organic production and closed-loop systems that maximise water and nutrient efficiencies. Such systems have major potential for the realisation of environmentally sustainable urban food and fuel production and have a very real part to play in adding value to society through zoo and botanic garden horticulture in the twenty-first century.

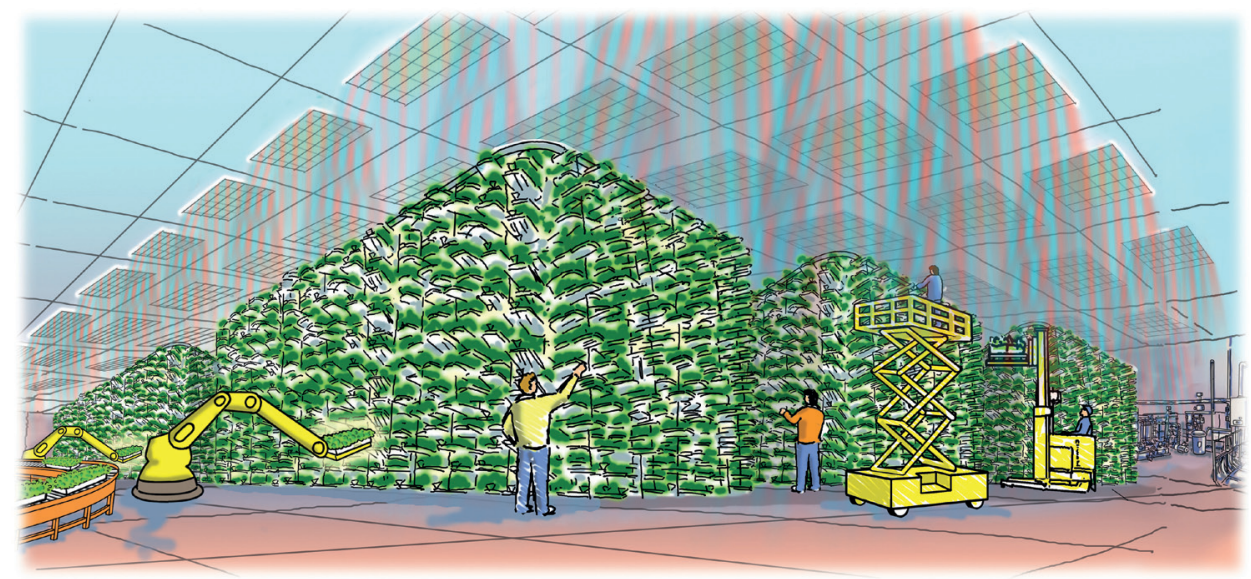

Fig. 4 VertiCrop ${ }^{\mathrm{TM}}$ is a modular high-density growing system suited to serving the needs of an urban agriculture. Photo of interpretation board: Chris Mutter. 


\section{REFERENCES}

BAKER, J. (1988). Chimps, Champs and Elephants. SJH Publications Limited, Paignton.

BAYLEY, J. (2010). VertiCrop ${ }^{\mathrm{TM}}$ yield and environmental data. Valcent (EU) Ltd., Launceston.

BAYLEY, J., FREDIANI, K.L. \& YU, M. (2010). Sustainable Food Production for the 21st century - VertiCrop ${ }^{\mathrm{TM}}$ High Density Vertical Growing. International Society of Horticultural Science (ISHS). In press. Proceedings from the 2010 International Conference of Horticulture, Lisbon; Acta Horticulturae, CAB International, Wallingford.

CHESTER, R. (2010). Technology brings polytunnels up to date. Horticulture Week, 5 March. Available at: http://www.hortweek.com/news/search/987541/Technology-bringspolytunnels-date/ (accessed May 2010).

CRANE, P. \& KINZIG, A. (2005). Nature in the metropolis. Editorial. Science, 308 (May 2005), 1,225 .

CRUZ, M.A. \& MEDINA, R.S. (2003). Agriculture in the City: A Key to Sustainability in Havana, Cuba. Outcome of the Research Project Evaluation of Urban Agriculture as a Component of the Local Economy in Two Areas of Havana, Cuba. Ian Randle Publishers, Kingston and International Development Research Centre.

DESPOMMIER, D. (2010). The Vertical Farm Project. Available online: http://www. verticalfarm.com/index.html (accessed 2 April 2010).

FISCHETTI, M. (2009). Growing vertically. Scientific America Earth 3.0, special edition, October 2008. Nature Publishing Group, 74-80.

FREDIANI, K.L. (2009a). The ethical use of plants in zoos: informing selection choices, uses and management strategies. International Zoo Yearbook, 43, 29-52.

FREDIANI, K.L. (2009b). Exploring the potential for plant-based enrichment. International Conference for Environmental Enrichment (ICEE) 2009 Conference Proceedings. In press.

FREDIANI, K.L. (2009c). High Density Vertical Growing as a public exhibit in the zoo. PlantNetwork News, June 2009. PlantNetwork, Cambridge.

FREDIANI, K.L. (2010). Feeding time at the Zoo. The Horticulturalist, April 2010. Institute of Horticulture, 12-15.

HAMPWAYE, G., ETIENNE, N. \& INGOMBE, L. (2009). The Role of Urban Agriculture in Addressing Household Poverty and Food Security: The Case of Zambia. The Global Development Network Working Paper, 19 (September 2009), New Delhi.

JACKSON, T. (2009). Prosperity without growth? The transition to a sustainable economy. Sustainable Development Commission. HMSO. Earthscan, London.

MEARS, D.R. (2007). Energy used in food production of food, feed, and fibre, in FLEISHER, D.H., TING, K.C. \& RODRIGUEZ, L.F. (eds). System Analysis and Modelling in Food and Agriculture. Encyclopedia of Life Support Systems (EOLSS), developed under the auspices of UNESCO, EoLSS Publishers, Oxford. Available online: www.eolss.net (accessed 10 May 2010).

MORGAN, L. (2009). Zoo ponics: the VertiCrop ${ }^{\mathrm{TM}}$ hydroponic system at Paignton Zoo. Maximum Yield Indoor Gardening, January 2010, 102-107. 
NEWMAN, P. \& JENNINGS, I. (2008). Cities as Sustainable Ecosystems. Island Press, Washington, DC.

ODUM, E.P. (1993). Ecology and Our Endangered Life-Support Systems. Sinauer Associates, Sunderland, MA.

ODUM, E.P. \& BARRETT, G.W. (2005). Fundamentals of Ecology 5th Edition. Thomson Brooks/Cole, Belmont, CA.

TURNER, I. (2009). Measuring Performance: Environmental Management Systems.

International Zoo Yearbook, 43, 82-90.

VOGAL, G. (2008). Upending the traditional farm. Science, 3, 198 (February 2008), 752-753.

WEIDEMA, B.P., THRANE, M., CHRISTENSEN, P., SCHMIDT, J. \& LOKKE, S. (2008).

Carbon footprint: A catalyst for life cycle assessment? Journal of Industrial Ecology, 12(1), 3-6.

WHITLEY WILDLIFE CONSERVATION TRUST (2009). Annual Report: Paignton Zoo, Living Coasts \& Newquay Zoo. Paignton Zoo Environmental Park, Paignton. 